\title{
Nature And Trend Of Female Participation In Higher Education In Assam: A Case Study Of Gauhati University
}

\section{Sourav Saha}

Research Scholar, Department of Geography, Gauhati University. Email: sourav.saha626@gmail.com

\begin{abstract}
Higher education plays a crucial role in socio-economic transformation of a country. At present the rate of female participation in higher education has been increasing, especially in the urban and sub-urban areas of the State Assam. But this scenario is very much disheartening in the State's rural areas. Very recently, some new universities have been established in Assam which makes the rate of female participation in higher education increased. However, the involvement of female in different technical and job oriented courses is still lagging behind. The present study is therefore an attempt to analyse the trend and pattern of women participation in different faculties of Gauhati University and also to investigate the socio-cultural factors behind the low rate of female participation in some particular faculties. The study is based on secondary data collected from the office of the university.
\end{abstract}

Keywords:

Participation of women, higher education, socio-economic factors

Article Received: 18 October 2020, Revised: 3 November 2020, Accepted: 24 December 2020

\section{Introduction}

Higher education plays a crucial role in socioeconomic transformation of a country (Zhang, 2010). In the development of a country, elementary education helps to create the foundation while higher education helps to make human intelligence, decision making efficiency, planning management skills and power of imagination (Dey and Halder, 2014). At present, India has the third largest higher education system in the world, next to China and United States. Although, women consists of almost half of the total population of the country and the female literacy rate is also increasing gradually but the rate of female participation in higher education is still quite low (Chauhan, 2011). At the same time, women education in India is still largely influenced by the socio-cultural and religious factors (Deen, 2014).Higher education of women is considered an important instrument for the development of society, because women are the backbone of our society, mother of our race and guardian of our future generation. The North Eastern part of India is economically backward but socio-culturally, the region is very rich and diverse and the status of women in the society is also higher as compared to other parts of the country. The female participation in education as a whole, and higher education in particular, was very low. But gradually, the scenario has been changing significantly over time. The present trend of female participation in higher education in the state of Assam shows a fairly increasing rate but the nature of participation is mainly controlled by several socio-cultural factors. The number of female participants is higher from urban and suburban areas than from rural areas. The present paper attempts to address the disparity in the nature and trends of male-female participation in higher education and their problems based on the findings from a case study of Gauhati University while placing special emphasis on the past and present status of female student enrolment.

\section{Study area}

The present study has been carried out at Gauhati University which is the oldest and prestigious university in North-Eastern Region of India. The institution is located in Guwahati city, Kamrup Metropolitan District of Assam. It was established in the year 1948, just after the independence of the country. Presently, the university has around 326 affiliated Colleges/Institutes, most of which are 
located in the districts of Lower Assam. It has 49 departments under 6 academic units and a population of over 5000, including 3000 students residing in hostels. Most of the students are residents of Assam. A significant number of students from different states of North East India and West Bengal are also enrolled in the University. Thus, the academic hinterland of this university mainly includes the seven states of North-East India and West Bengal. In recent years, a few students from foreign countries such as Bangladesh, Bhutan, Iran and some African countries were found in this University.

\section{Database and Methodology}

This study is completely based on secondary data which were obtained from the Office of the Secretary of University Classes, Gauhati University, including journals and magazines published by the University. Data interval of every ten years beginning from 1961 till 2013 was used to find out the changing trends. The data so collected from secondary sources have been analysed quantitatively as well as qualitatively by applying suitable statistical and cartographic techniques for a clear spatio-temporal exposition of the situation.

\section{Results and discussion}

\section{Temporal scenario of student enrolment}

Since the time of Independence, India made a significant progress higher education. As per All India Survey on Higher Education (AISHE), 2011 report 27.5 million students enrolled in higher education with 15.5 million boys and 12.0 million girls. The girls constitute $44 \%$ of the total enrolment. Although, women participation in higher education in India is increasing over time but there is spatial-temporal variation across the country. Participation of women in higher education in Assam represents a unique pattern. If we look at the trend of student enrolment pattern at Gauhati University (the oldest higher education institute of the State) since 1961 to 2013, it will give a clear idea about the changing nature of student enrolment in higher education, particularly in Post Graduate courses (Table-1).

Table 1. Trends of student enrolment from 1961 to 2013

\begin{tabular}{|c|c|c|}
\hline \multirow{2}{*}{ Year } & \multicolumn{2}{|c|}{ Student enrolled in Post Graduate Courses } \\
\cline { 2 - 3 } & Male (in \%) & Female (in \%) \\
\hline 1961 & 92.14 & 7.86 \\
\hline 1971 & 64.94 & 35.06 \\
\hline 1991 & 59.74 & 40.25 \\
\hline 2013 & 30.98 & 69.86 \\
\hline
\end{tabular}

Source: Compiled from enrolment register, G.U, 1961 to 2013

The above table clearly indicates the low rate of female student enrolment to the university during the 1960s and 1970s. However, the improvement of socio-economic conditions of the people has led to the increasing number of female participation over time. It has been observed that during the last decade, the female participation has crossed the number of male students (Figure 1). In the year 1961, out of the total students the share of male student was $92.14 \%$ and female was only $7.86 \%$. The percentage of female students increased to $42.25 \%$ in 1991 and $69.86 \%$ in 2013. Nevertheless, the participation of male student showed a gradual decline trend. The proportion of male student to the total student, which was $92.14 \%$ in 1961 declined to $59.74 \%$ in 1991 and $30.98 \%$ in 2013.

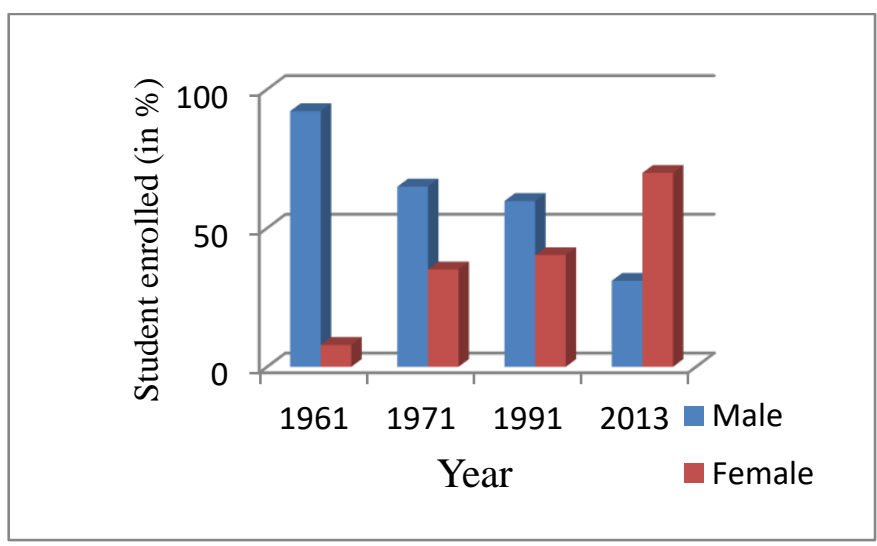

Figure 1. Gender-wise trend of student enrolment The changing pattern of student enrolment in terms of gender is not only influenced by one factor, but a combination of several factors 
including social and economic factors. Initially, the male students generally prefer obtain their master's degree. However, in due course of time, the enrolment patterns started changing. One important reason for gender-shift in favor females may be attributed to the growth of female literacy rate in the whole region of North East India. Improving economic conditions and the influence of urbanization likely enhanced participation of female students in the Post Graduate courses offered by the University. It is indeed a good indication of the women empowerment and should increase the contribution of women in the services sector. It may be worth mentioning here that India is a male-dominated country and men are generally more responsible for their family income as compared to women. In recent times, men are more interested in pursuing job-oriented careers and therefore, choose the courses related to management, engineering, etc., other than the general Post Graduate courses.

Spatial variation of female participation to the University
Student enrolment pattern at any educational institution is not static, it is dynamic one. It varies spatially and temporally. This is also true in the case of female participation at the Gauhati University. The spatial pattern of female student participation at the university shows a completely unique scenario. During 2013-2014 the total number of student was 1627 , out of which the total number of female was 1123 . But the spatial participation pattern is not uniform through the entire Academic Hinterland (Figure 2). Highest numbers of female students come from the nearby urban centers. The proportion of female students from the rural areas is very less in number. Out of the total female students, 23.15 per cent come from the Kamrup Metropolitan district only, followed by Kamrup Rural (10.42\%), Nagaon(8.28\%) Barpeta(7.12\%), Nalbari(6.77\%), Sonitpur(5.35\%) (Table 2 and Figure 3). On the other hand the Dhubri (1.60\%), Kokrajhar (2.31\%), Bongaigaon(1.33\%), Goalpara(2.31\%) districts shows very low percentage of female enrolment. It is the result of combination of various factors such as urbanization, distance from the university, cultural background, safety, etc.

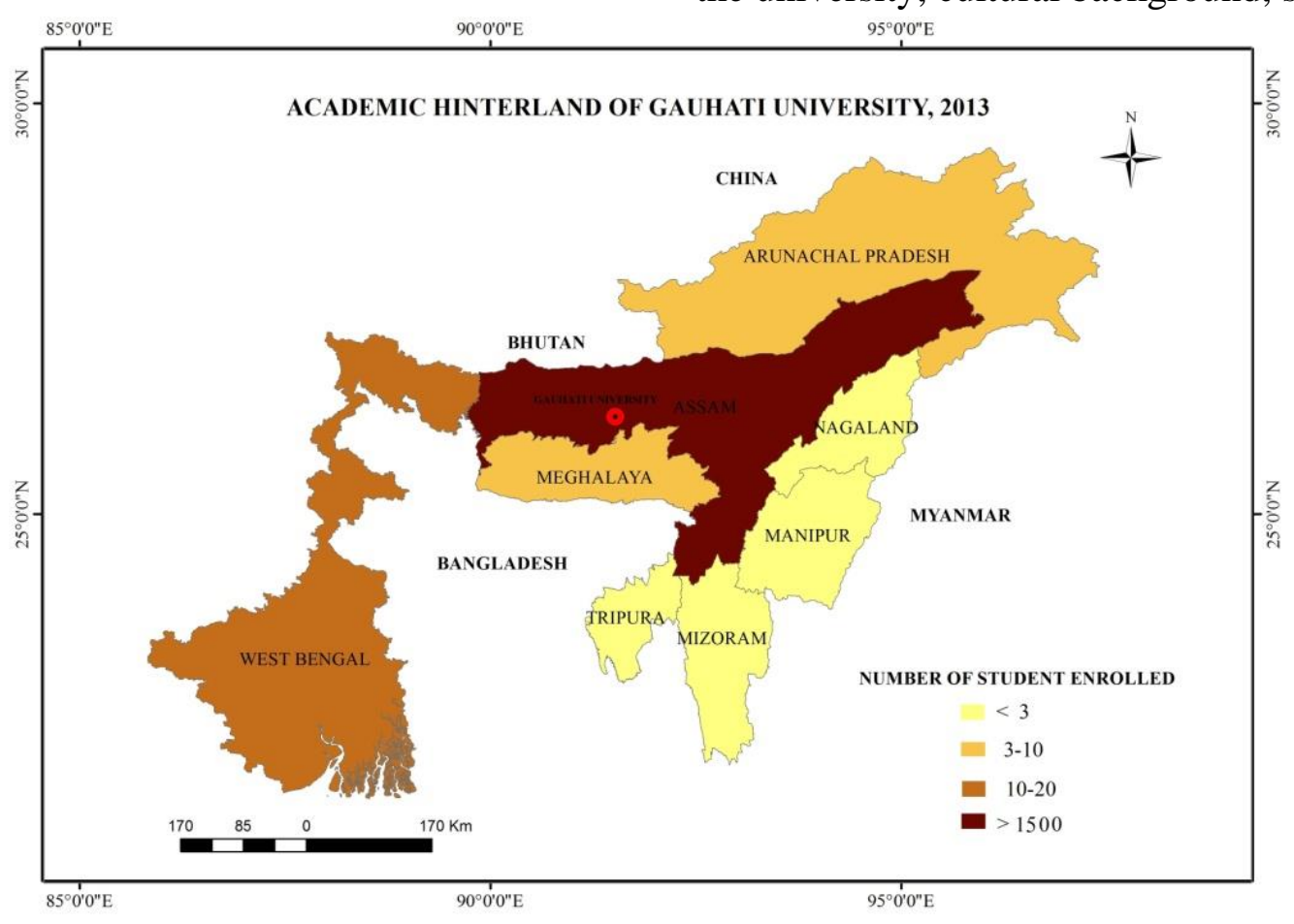

Figure 2. Pattern of student flow from the academic hinterland of Gauhati University 
Note: The boundary of the academic hinterland is delineated based on the residential address of the students enrolled in PG courses in 2013.

Table 2. Pattern of student flow to Gauhati University

\begin{tabular}{|c|c|c|c|c|c|c|}
\hline $\begin{array}{c}\text { District / } \\
\text { State }\end{array}$ & $\begin{array}{l}\text { No. of } \\
\text { student }\end{array}$ & $\begin{array}{c}\% \text { to the } \\
\text { total } \\
\text { student }\end{array}$ & $\begin{array}{l}\text { No. of } \\
\text { male } \\
\text { student }\end{array}$ & $\begin{array}{l}\% \text { to the } \\
\text { total male }\end{array}$ & $\begin{array}{l}\text { No. of } \\
\text { female } \\
\text { student }\end{array}$ & $\begin{array}{c}\% \text { to the } \\
\text { total } \\
\text { female }\end{array}$ \\
\hline Dhubri & 42 & 2.58 & 24 & 4.76 & 18 & 1.06 \\
\hline Kokrajhar & 37 & 2.27 & 11 & 2.18 & 26 & 2.31 \\
\hline Bongaigaon & 33 & 2.02 & 18 & 3.57 & 15 & 1.33 \\
\hline Goalpara & 33 & 2.02 & 13 & 2.57 & 2 & 2.31 \\
\hline Barpeta & 136 & 8.36 & 56 & 11.11 & 80 & 7.12 \\
\hline Nalbari & 107 & 6.57 & 31 & 6.15 & 76 & 6.77 \\
\hline Kamrup(R) & 162 & 9.95 & 45 & 8.93 & 117 & 10.42 \\
\hline Kamrup(M) & 346 & 21.26 & 86 & 17.06 & 260 & 23.15 \\
\hline Darrang & 71 & 4.36 & 26 & 5.15 & 45 & 4.00 \\
\hline Sonitpur & 81 & 4.97 & 21 & 4.17 & 60 & 5.35 \\
\hline Lakhimpur & 52 & 3.19 & 19 & 3.77 & 33 & 2.94 \\
\hline Dhemaji & 12 & 0.73 & 1 & 0.19 & 11 & 0.97 \\
\hline Morigaon & 45 & 2.76 & 8 & 1.58 & 37 & 3.29 \\
\hline Nagaon & 138 & 8.48 & 45 & 8.93 & 93 & 8.28 \\
\hline Golaghat & 22 & 1.35 & 6 & 1.19 & 16 & 1.24 \\
\hline Jorhat & 33 & 2.02 & 9 & 1.78 & 24 & 2.13 \\
\hline Sibsagar & 22 & 1.35 & 11 & 2.18 & 11 & 0.97 \\
\hline Dibrugarh & 23 & 1.53 & 4 & 0.79 & 19 & 1.70 \\
\hline Tinsukia & 25 & 1.53 & 4 & 0.79 & 21 & 1.87 \\
\hline Karbianglong & 23 & 1.41 & 6 & 1.19 & 17 & 1.51 \\
\hline Karimganj & 1 & 0.06 & 1 & 0.19 & - & - \\
\hline Hailakandi & 4 & 0.24 & 1 & 0.19 & 3 & 0.26 \\
\hline Cachar & 3 & 0.18 & - & - & 3 & 0.26 \\
\hline Chirang & 29 & 1.78 & 5 & 0.99 & 24 & 2.13 \\
\hline Udalguri & 46 & 2.82 & 16 & 3.18 & 30 & 2.67 \\
\hline Baksa & 46 & 2.28 & 13 & 2.57 & 33 & 2.99 \\
\hline Dima Hasao & 18 & 1.10 & 3 & 059 & 15 & 1.33 \\
\hline Meghalaya & 7 & 0.18 & 5 & 0.99 & 2 & 0.17 \\
\hline Arunachal & 5 & 0.30 & 1 & 0.09 & 2 & 0.35 \\
\hline Manipur & 3 & 0.18 & 2 & 0.29 & 1 & 0.08 \\
\hline Mizoram & 3 & 0.18 & 1 & 0.19 & 2 & 0.17 \\
\hline Nagaland & 1 & 0.06 & 1 & 0.19 & - & - \\
\hline Tripura & - & - & - & - & - & - \\
\hline West Bengal & 17 & 1.04 & 11 & 2.18 & 6 & 0.53 \\
\hline Total & 1627 & 100 & 504 & 100 & 1123 & 100 \\
\hline
\end{tabular}

Source: Compiled from enrolment register, G.U.,2013 


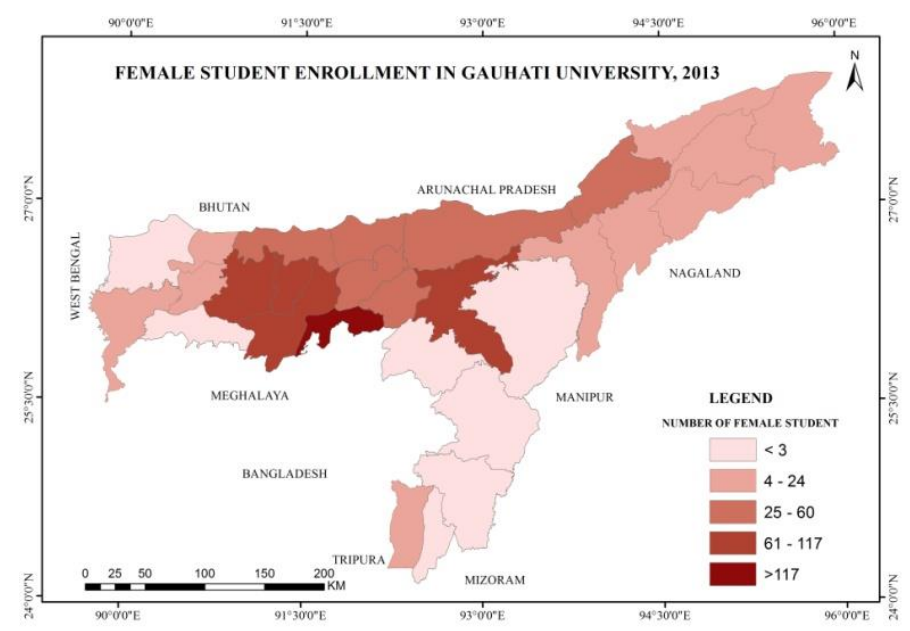

Figure 3. Spatial pattern female student participation to Gauhati University

Gender disparity in subject choices

Subject choice in higher education and its relation to gender has become one of the major concern issue (Chanana, 2007). It is seen that in India, science and engineering/ technical courses are masculine dominated discipline and humanities and arts subjects are feminine subjects. The analysis of student enrolment and their subject choice in Gauhati University also prove the same trend. It has been observed that some department have prevailing trend of female student enrolment more than that of male student. From the last two decade the trend of female student enrolment to the some specific department increasing day by day. Basically the literature department such as Assamese, Bengali, Bodo, English, Hindi, Sanskrit etc has higher trend of female student enrolment. Out of total student enrolment of these departments in the academic session 2013-2014 about more than 80 per cent students were female (Table 3: and Figure 4).

Table 3. Enrolment Pattern in Selected Arts and Humanities Department, 2013

\begin{tabular}{|l|c|c|c|}
\hline \multicolumn{1}{|c|}{ DEPARTMENT } & TOTAL STUDENT & MALE (in \%) & FEMALE (in \%) \\
\hline Arabic & 60 & 60 & 40 \\
\hline Assamese & 88 & 10.22 & 89.77 \\
\hline Bengali & 38 & 21.10 & 78.90 \\
\hline Bodo & 45 & 13.33 & 86.66 \\
\hline Education & 53 & 7.54 & 92.46 \\
\hline English & 66 & 9.09 & 90.91 \\
\hline Hindi & 50 & 20.00 & 80.00 \\
\hline Psychology & 29 & 3.44 & 96.66 \\
\hline Sanskrit & 69 & 10.19 & 89.81 \\
\hline Sociology & 45 & 17.78 & 82.22 \\
\hline
\end{tabular}

Source: Compiled from enrolment register, G.U,2013 


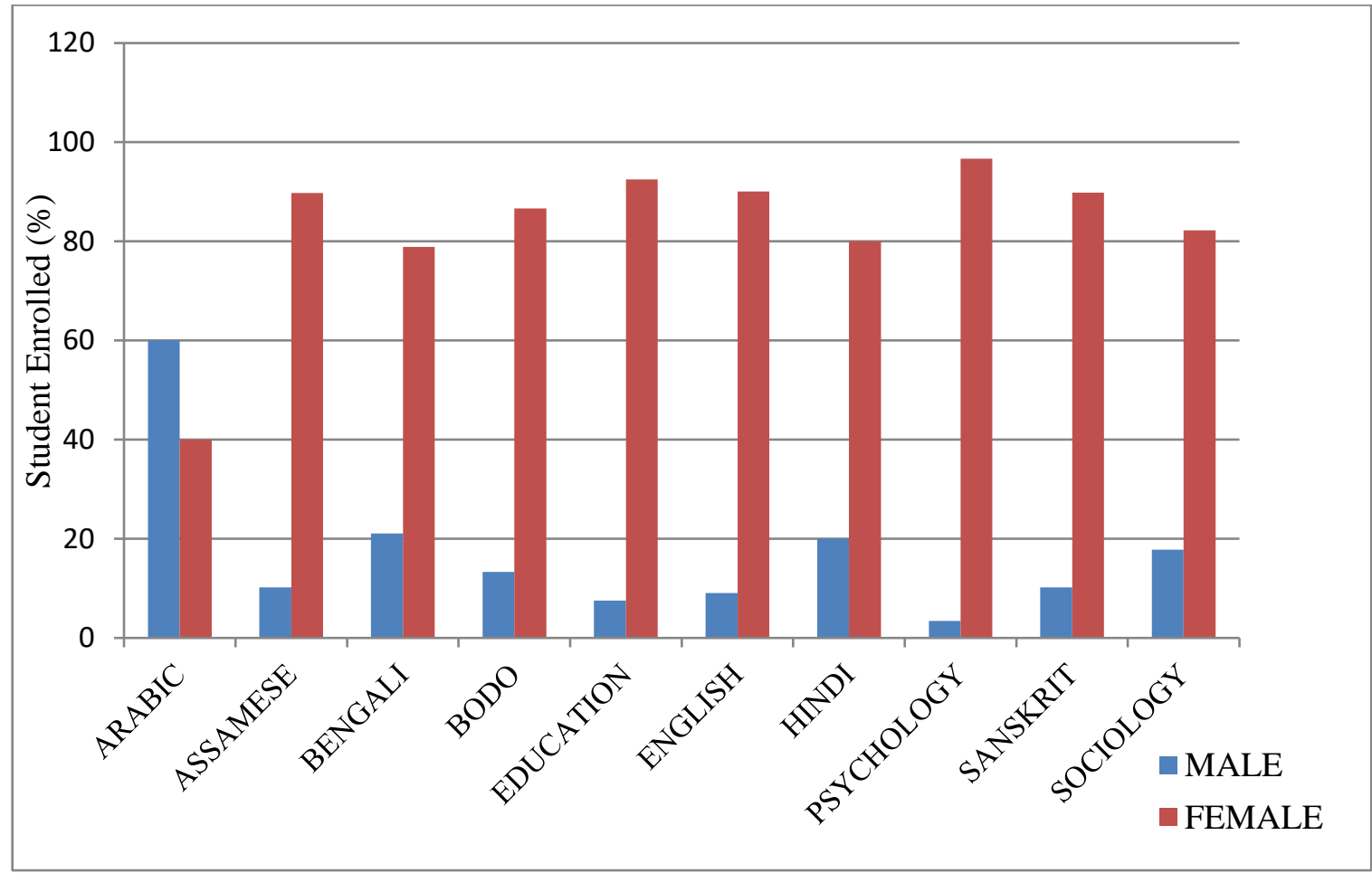

Figure 4. Enrolment Pattern in Selected Arts and Humanities Department, 2013

It may be worth mentioning here that although most of the literature department has more than 80 per cent female student but in case of the department of Arabic it is completely different. The female students were only 40 percent to the total student of this department in the academic year of 2013-2014. This is because of low female literacy rate among the Muslim population. Most of the Muslim communities of rural areas, females play the role of housewife and they are rarely allowed to work in mainstream economic activities. Even in the present scenario, they are still lagging behind in terms of education and are deprived of having equal status with the male. In case of urban areas, such problems comparatively less due in part to urbanization and the urban social structure. Although many female students are meritorious in the rural areas but their families are unlikely to send them to the university due to the far distance and socio-economic situation. Another important factor the low female participation in the department of Arabic is that of early marriage of the female. Most of the female from rural areas in general and Muslim communities in particular get married at a relatively young age.

There are many departments in the university where the numbers of female students is very less as compared to the male student. There are some departments under the faculty of science, technology and management such as Physics, Chemistry, Computer Science, Electronics, Instrumentation, Mathematics, M.Sc.IT, M.B.A etc, where the male student is comprised of more than 65 per cent of its total student and the share of female students is less than 35 per cent (Table 5 and Figure 5).

Table 5. Enrolment Pattern in Selected Science and Technical Department, 2013

\begin{tabular}{|l|c|c|c|}
\hline \multicolumn{1}{|c|}{ DEPARTMENT } & TOTAL STUDENT & MALE (in \%) & FEMALE (in \%) \\
\hline Chemistry & 46 & 47.82 & 52.17 \\
\hline Computer Science & 16 & 62.5 & 37.5 \\
\hline Electronics & 33 & 87.88 & 12.12 \\
\hline
\end{tabular}




\begin{tabular}{|l|c|c|c|}
\hline Instrumentation & 19 & 78.95 & 21.05 \\
\hline Mathematics & 80 & 55 & 45 \\
\hline M.B.A & 61 & 55.74 & 44.26 \\
\hline M.Sc. IT & 18 & 66.66 & 33.33 \\
\hline Physics & 51 & 62.74 & 37.26 \\
\hline
\end{tabular}

Source : Compiled from enrolment register, G.U,2013

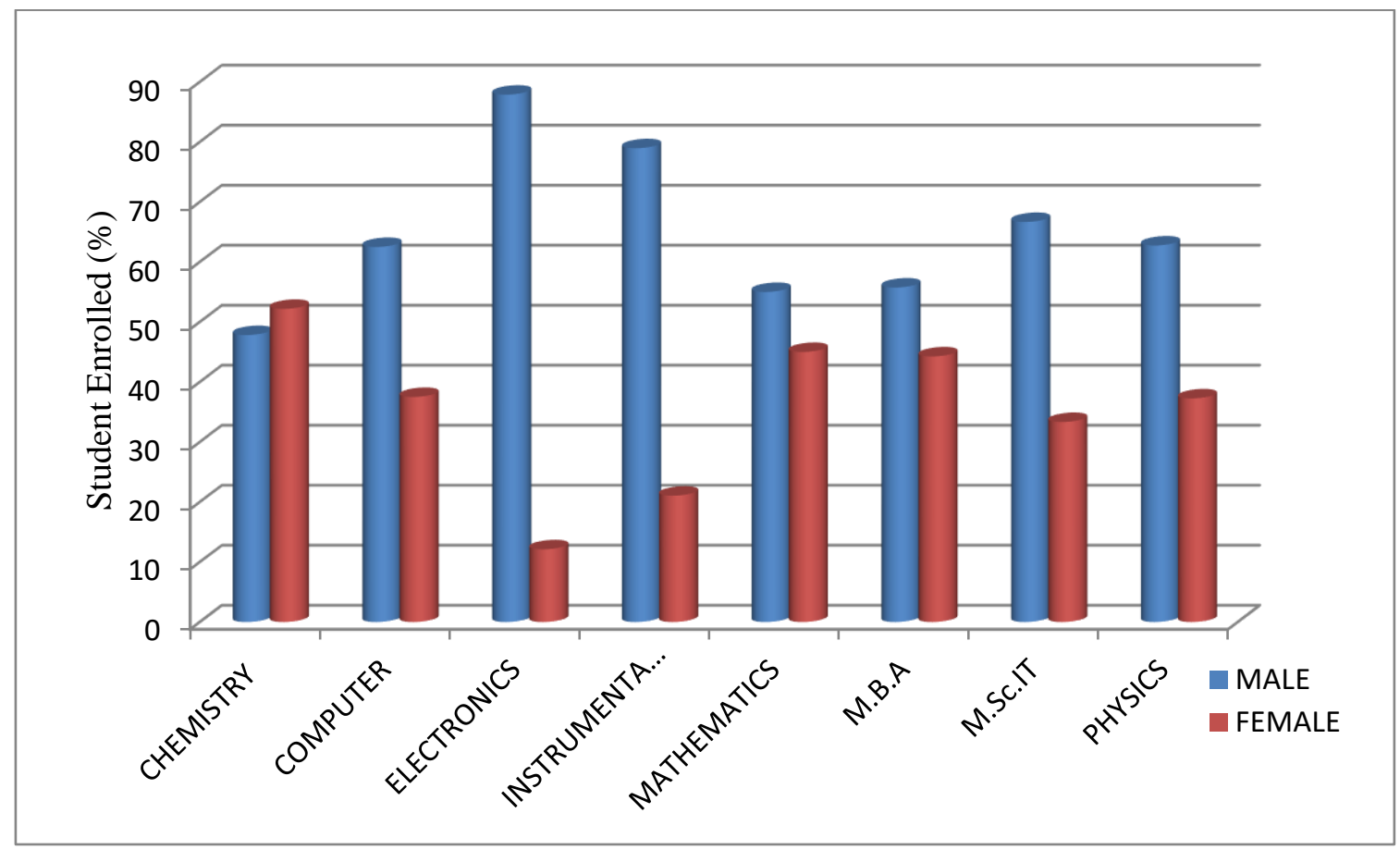

Figure 5. Enrolment Pattern in Selected Science and Technical Department, 2013

\section{Causes of Disparity}

The gender disparity of participation in higher education at the Gauhati University may be ascribed broadly to cultural and economic factors. It is found that most of the families, especially in rural areas have been giving undue favor to their son(s) with respect to decision making and career opportunities at the expense of their daughter(s). Educational expenditure is higher in the subjects of science, technology and management compared to the other social science and humanities subjects. Therefore male students from rural areas in particular are getting more preference from their parents to take science, technological and management subjects. Generally, job opportunities are significantly higher in science, technological and management subjects. Meritorious female students are often compelled to make a compromise in their choice of education due to lack of family support. Most of the families in our societies think that after getting married, females would be taking the responsibility of their in-law's home. Consequently, the opportunity to advance their careers diminishes. There are also instances where parents prefer to educate their daughter only for marriage purpose. They think that if their daughters get educated after taking subjects that require low expenses, it will be much easier for them to get married. The reasoning behind this is that the demand for their daughter would then increase and she would easily be able to get an economically well-off family. From this point, we can find a distinction between the thinking of parents from urban areas and rural areas towards the girl child in the context of higher education. The parents of urban areas have given importance to the education and well-being of their children equally, irrespective of gender. 
However, these conditions may vary depending on the social background, education and economic status of the families. In recent times, these traditions have been changing under the influence of urbanization and economical development of the society. Due to these factors, a fairly increasing rate of female participation in higher education has been observed. But the female students from remote villages are likely still facing these types of problems. Another important cause of the decreasing trend in male student participation in P.G courses, especially in arts and humanities field may be due to the lack of job opportunities despite the amount of time investment that is required in those courses. There is a misconception in our society that males are more responsible for looking after their families. Therefore, most of the male students are indirectly pressured to take short term job-oriented and professional courses that require less time but more career opportunities.

\section{Conclusion}

From the foregoing discussion it is clear that the female participation in higher education in Assam is started increasing during last three decades. However, there is a significant spatial variation in female student enrolment pattern. Distance from the university and influence of urbanization are the two most influential factors of this spatial variation. Similarly, there is a significant disparity in student enrolment pattern especially in terms of subject choice. As compare to the male student female were found more intended toward humanities, linguistics and social science subjects. Proportion of female student enrolment in scientific and technical courses is still very limited. Socio-economic status and cultural background the students are also plays a vital role. With the growing number of female student participation in higher education, higher enrolment in scientific and technological courses is also necessary.
[1] Barthakur, A. (1995): 'Opinion of the students of Cotton College Regarding Higher Education', an unpublished M.A Dissertation, Cotton College, Gauhati University.

[2] Chanana, K. (2007). Globalisation, higher education and gender: Changing subject choices of Indian women students. Economic and Political Weekly, 590-598.

[3] Chauhan, C. P. S. (2011), Participation of Women in Higher Education: The Indian Perspective, Analytical Reports in International Education, 4(1), 67-86.

[4] Das.I. (2013): Status of Women: North Eastern Region of India Versus India, International Journal of Scientific and Research Publication, Vol.-3, Issue-1

[5] Dehdarirad, T., Villarroya, A., \& Barrios, M. (2015). Research on women in science and higher education: a bibliometric analysis. Scientometrics, 103(3), 795-812.

[6] Dey and Halder (2014): Present Status of Women in Higher Education in West Bengal: An Appraisal, International Journals of Humanities and Social Science Studies. Vol.- I, Issue-III, PP-166-172.

[7] Deen, S. (2014). Women in higher education: A spatial-temporal analysis of higher education from gender perspective in India. Learning Community: An International Journal of Educational and Social Development, 5(2/3), 173.

[8] Nair, N. (2010). Women's education in India: A situational analysis. IMJ, 1(4).

[9] Renju.A(2014): Higher Education and Women Participation in India, Global Journal for Research Analysis, Vol.-3, Issue-6.

[10] Zhang, S. (2010). Narrative research of female educational experiences in China. Frontiers of Education in China, 5(4), 596-616.

\section{References}

